\title{
Soil Nematode Trophic Groups in Four Different Plantations in Southern China: Implications for Restoration
}

\author{
Cancan Zhao ${ }^{1}$, Feng Sun ${ }^{1,2}$, Chengde Yu${ }^{1}$, Lili Zhu ${ }^{1}$, Ying $\mathrm{Li}^{1}$, Zhenxing Zhou ${ }^{1}$, \\ Guangfei Yang ${ }^{1}$, Wenjuan Wang ${ }^{1}$, Renhui Miao ${ }^{1 *}$ \\ ${ }^{1}$ International Joint Research Laboratory for Global Change Ecology, College of Life Sciences, \\ Henan University, Kaifeng, Henan 475004, China \\ ${ }^{2}$ Chengdu Institute of Biology, Chinese Academy of Sciences, Chengdu, Sichuan 610041, China
}

Received: 27 June 2017

Accepted: 15 September 2017

\begin{abstract}
Intensive anthropogenic disturbances have caused forest ecosystem degradation and soil erosion. Exotic fast-growing species are selected as pioneer species for restoration in degraded hilly lands of southern China. To better understand the potentials of the soil nematode trophic group composition in carbon sequestration, we investigated nematode trophic groups in Acacia, Eucalyptus, and Schima (native species as control) monoculture plantations in southern China after 23 years of reforestation. Our results showed that although total soil nematode abundance was not affected, the Acacia plantation significantly altered nematode trophic group composition over native species. Bacterivore and microbivore abundance, trophic diversity, and microbivore-driven soil organic carbon storage were higher in Acacia mangium than Schima superba. In contrast, plant parasitic nematode abundance and fungivore/bacterivore ratio were lower in Acacia mangium than Schima superba. As a result, Acacia mangium as a fast-growing pioneer tree species could be widely planted to maintain soil biodiversity and store carbon in restoring degraded forests in southern China. Eucalyptus exserta plantation enlarged the soil nematode community, including bacterivores, fungivores, and herbivores, suggesting that there is almost no allelopathy when eliminating anthropogenic disturbance in this study. Reasonable management is crucial for providing timber products and improving the ecological function of Eucalyptus plantations. Our results also highlight the critical roles of soil water and nutrient availability in regulating soil nematode trophic group composition and carbon sequestration.
\end{abstract}

Keywords: ecosystem restoration, soil biota, microbivore, Acacia, Eucalyptus

*e-mail: miaorenhui@henu.edu.cn 


\section{Introduction}

Plants are the source of life in a terrestrial ecosystem. They perform many ecological functions and shape the lives of living things in the environment where they live. Life is directly or indirectly dependent on plants [1-3]. The ability of plants to fulfill their functions primarily depends on the availability of appropriate climatic and edaphic conditions [4-5]. Therefore, soil is one of necessary conditions for a plant's existence, which is essential for living things. Soil, which has a complex structure, provides the basis for biological and biochemical processes. It is important to examine the changes in soil and its relationship with plants.

In the last few decades, intensive anthropogenic disturbances for economic development have greatly affected terrestrial ecosystems and caused a series of environmental problems such as forest degradation, biodiversity loss, and soil erosion. Forests, accounting for approximately $27 \%$ of the earth's land surface, play an important role in maintaining biodiversity, strengthening carbon sequestration capacity, and conserving water and soil [6-7]. Establishing forest plantation in degraded habitats is widely accepted as an effective approach to restore and rehabilitate the ecosystem through natural succession without anthropic disturbance [8]. Most previous studies focus on assessing vegetation recovery or soil organic matter accumulation during a degraded ecosystem's restoration [9-11]. Therefore, exploring how soil organisms respond to restoration is important for evaluating ecosystem restoration.

Soil organisms, including soil microorganisms and soil fauna, play a major role in organic matter decomposition and nutrient cycling [12]. Nematodes are the most abundant multi-cellular organisms in soil and are well adapted to a wide range of environmental conditions. Nematodes respond to disturbance rapidly and occupy key positions at all consumer trophic levels (bacterivore, fungivore, herbivore, omnivore, and predator) in the soil food web. Therefore, soil nematode trophic group composition can give insights into the structure and function of the soil ecosystem due to their crucial regulative roles in the microbial community [13]. Some previous studies have reported that nematodes are widely used as biotic indicators of conservation or disturbance, nutrient enrichment, and pollution of soils [14-17]. However, less attention has been paid to the application of soil nematodes as bio-indicators to evaluate the long-term natural recovery of degraded ecosystems.

In southern China artificial forests have been established enormously in degraded hilly areas for ecological restoration during the past 50 years. Exotic fast-growing species such as Acacia and Eucalyptus are generally selected as pioneer species for reforestation due to their higher productivity and tolerance to barren and acidic soils [18]. In this study, reforestation with different tree species including Acacia, Eucalyptus, and Schima (native species as control) monoculture plantations have been conducted in degraded hilly lands of southern
China since 1983. To evaluate the soil restoration of different plantations and select an applicable pioneer species, we detected the changes in soil nematode trophic groups after 23 years of reforestation. Since Acacia as leguminous plants could fix nitrogen into soil due to its symbiosis with rhizobia, we hypothesized that Acacia soil would accumulate more nutrient substance and support a higher abundance of microbivorous nematodes. Given that Eucalyptus allelopathy is likely to inhibit understory plant growth, our second hypothesis is that Eucalyptus would suppress soil nematode abundance and diversity. We also hypothesized that soil nematode composition may vary with seasonal variability due to changes in water and nutrient availability.

\section{Materials and Methods}

\section{Description of Study Site}

The experimental site was located at Heshan National Field Research Station of Forest Ecosystem (22 $34^{\prime} \mathrm{N}$, $112^{\circ} 50^{\prime} \mathrm{E}, 80 \mathrm{~m}$ a.s.1.), Chinese Academy of Sciences, Guangdong, China. The climate is subtropical monsoon with a distinct dry (from October to March) and wet (from April to September) season. The mean annual precipitation is $1,700 \mathrm{~mm}$ with $80 \%$ of the precipitation occurring during the wet season. The mean annual temperature is $21.7^{\circ} \mathrm{C}$, and the maximum and the minimum temperatures are $29.2^{\circ} \mathrm{C}$ in July and $12.6^{\circ} \mathrm{C}$ in January. Mean annual evaporation is $1600 \mathrm{~mm}$. The soil is classified as Acrisol according to the United Nations Food and Agriculture Organization. The mean slope of the hilly land is $28^{\circ}$.

The zonal climax vegetation is subtropical monsoon evergreen broad-leaved forest. From 1950 to 1980 the forests were severely damaged due to excessive utilization, resulting in vegetation degradation and soil erosion. The dominants species were shrub and herbaceous species such as Ischaemum indicum, Eriachne pallescens, and Baeckea frutescens. In 1983, four experimental monoculture plantations were established to restore the degraded ecosystems. All plantations were left to develop naturally without anthropogenic disturbance [19].

\section{Soil Sampling and Analysis}

The sampling sites were selected in the 12 catchment regions. Each catchment region, which occupied approximately 1 ha, was one of three replications of the four monoculture plantations: Schima superba (SS), Acacia mangium (AM), Acacia auriculaeformis (AA), and Eucalyptus exserta (EE). In each catchment region three $10 \times 10 \mathrm{~m}^{2}$ sampling blocks were randomly established on the upper slope, mid slope, and lower slope to eliminate the effect of slope. Soil samples were collected from the root and non-root zones, which were defined as close to trunk and far away from trunk in all the blocks. After the surface litter was removed carefully, five soil cores of $0-10 \mathrm{~cm}$ depth were randomly taken using a $3 \mathrm{~cm}$ diameter 
auger in each plot, and combined to form one composite sample. Soil samples were collected on 9 November 2006 (dry season) and 11 May 2007 (wet season). Total soil sample numbers were 144. After passing through a $2 \mathrm{~mm}$ sieve and the removal of visible roots and stones by hand, subsamples were used for nematode extraction and identification, soil moisture, and dissolved organic carbon analyses. The other subsamples were air-dried for chemical analysis.

Gravimetric soil moisture was measured by ovendrying for $24 \mathrm{~h}$ at $105^{\circ} \mathrm{C}$. Soil $\mathrm{pH}$ was determined in a soil water mixture of 1:2.5 (w/v) using a digital $\mathrm{pH}$ meter. Soil organic carbon was determined by the oxidation of $\mathrm{H}_{2} \mathrm{SO}_{4} / \mathrm{K}_{2} \mathrm{Cr}_{2} \mathrm{O}_{7}$ and titration with $\mathrm{FeSO}_{4}$. Soil total nitrogen was measured using an ultraviolet spectrophotometer after Kjeldahl digestion. Dissolved organic carbon was extracted from moist $20 \mathrm{~g}$ soil samples after being shaken for $30 \mathrm{~min}$ in $60 \mathrm{ml}$ of $0.5 \mathrm{M} \mathrm{K}_{2} \mathrm{SO}_{4}$. The extracts were filtered and measured by a total organic carbon analyzer (Elementar vario TOC, Elementar Co., Germany).

Nematodes were extracted from $50 \mathrm{~g}$ of fresh soil using the Baermann funnel method. After fixation in $4 \%$ formaldehyde solution, nematodes were counted with an inverted microscope (Eclipse Ts100, Nikon). In each sample, the first 100 individuals were identified to four trophic groups, i.e., bacterivores, fungivores, herbivores, and omnivore-predators. All nematodes were identified when the sample contained fewer than 100 individuals.

\section{Statistical Analysis}

Nematode data were transformed using $\ln (x+1)$ to meet assumptions of normality and homogeneity of variance. Trophic diversity index (TDI) was calculated by TDI $=1 / \sum p i^{2}$, where $p i$ is the proportion of individuals of the $i$ th trophic group in the total community [20]. The effects of season, forest type, slope, root zone, and their potential interactions on soil and nematode properties were analyzed using four-way ANOVAs. Multiple comparisons were conducted to examine the effects of forest type on soil and nematode properties in both dry and wet seasons. Simple linear regressions were performed to assess the relationships of nematode properties and abiotic factors in dry and wet seasons. All statistical analyses were performed using SPSS 17.0 software (SPSS Inc., Chicago, USA). LSD was used to test differences among treatments.

\section{Results}

\section{Soil Properties}

Soil moisture varied with season (Table 1). Mean soil moisture in wet season $(28.4 \%)$ was higher than that

Table 1. Results (F values) of four-way ANOVAs for the effects of season (S), forest type (F), slope (Sl), root zone (R), and their potential interactions on soil moisture $(\mathrm{SM})$, soil $\mathrm{pH}$, soil organic carbon (SOC), total nitrogen (TN), nematode abundance $(\mathrm{N})$, trophic diversity index (TDI), bacterivore abundance (B), fungivore abundance $(\mathrm{F})$, herbivore abundance $(\mathrm{H})$, omnivore-predator abundance $(\mathrm{O})$, fungivores/bacterivores ratio $(\mathrm{F} / \mathrm{B})$, and (fungivores+bacterivores)/herbivores $((\mathrm{F}+\mathrm{B}) / \mathrm{H})$.

\begin{tabular}{|c|c|c|c|c|c|c|c|c|c|c|c|c|}
\hline $\begin{array}{c}\text { Source of } \\
\text { variation }\end{array}$ & $\mathrm{SM}$ & $\mathrm{pH}$ & $\mathrm{SOC}$ & $\mathrm{TN}$ & $\mathrm{N}$ & $\mathrm{TDI}$ & $\mathrm{B}$ & $\mathrm{F}$ & $\mathrm{H}$ & $\mathrm{O}$ & $\mathrm{F} / \mathrm{B}$ & $(\mathrm{F}+\mathrm{B}) / \mathrm{H}$ \\
\hline Season (S) & $187.0^{* * *}$ & $92.6^{* * *}$ & 3.6 & $12.8^{* * *}$ & $8.7^{* *}$ & $10.7^{* * *}$ & $64.2^{* * *}$ & $3.9^{*}$ & 0.0 & 0.0 & $4.7^{*}$ & $46.3^{* * *}$ \\
\hline Forest type (F) & $38.8^{* * *}$ & $14.8^{* * *}$ & $37.6^{* * *}$ & $34.7^{* * *}$ & $5.5^{* *}$ & $5.9^{* * *}$ & $9.1^{* * *}$ & $6.8^{* * *}$ & $5.0^{* *}$ & 1.0 & $3.9^{*}$ & 2.1 \\
\hline Slope (Sl) & 0.1 & 0.1 & 0.6 & 1.1 & $3.6^{*}$ & $3.9^{*}$ & 0.7 & 0.1 & $4.4^{*}$ & 1.8 & 0.6 & 2.2 \\
\hline Root zone (R) & 1.4 & $12.6^{* * *}$ & $9.8^{* *}$ & $5.7 *$ & 0.2 & 0.7 & 0.1 & 0.1 & 0.5 & 0.6 & 1.9 & 0.5 \\
\hline $\mathrm{S} \times \mathrm{F}$ & 2.0 & $11.2^{* * *}$ & 1.9 & 2.5 & $7.1 * * *$ & 1.3 & $9.7 * * *$ & 1.8 & $4.9^{* *}$ & $2.8^{*}$ & $3.8^{*}$ & $3.4^{*}$ \\
\hline $\mathrm{S} \times \mathrm{Sl}$ & 0.9 & 0.1 & 0.7 & 0.8 & 0.4 & 0.9 & 0.5 & 0.2 & 0.5 & 1.4 & 0.3 & 0.2 \\
\hline $\mathrm{S} \times \mathrm{R}$ & 0.0 & $5.4 *$ & 2.7 & 1.0 & 0.6 & 0.5 & 1.4 & 0.1 & 0.8 & 0.1 & 2.6 & 0.4 \\
\hline $\mathrm{F} \times \mathrm{Sl}$ & 0.4 & $2.4 *$ & 0.5 & 0.7 & 0.7 & $5.4 * * *$ & 1.0 & 1.7 & 1.3 & 0.6 & 0.6 & $4.1 * *$ \\
\hline $\mathrm{F} \times \mathrm{R}$ & 0.2 & 2.6 & 1.1 & 1.2 & 0.2 & 0.2 & 0.6 & 1.6 & 0.2 & 0.2 & 1.7 & 1.0 \\
\hline $\mathrm{Sl} \times \mathrm{R}$ & 0.1 & $3.7 *$ & 0.1 & 0.2 & 0.3 & 0.5 & 0.3 & 1.1 & 0.1 & 0.8 & 0.2 & 0.1 \\
\hline $\mathrm{S} \times \mathrm{F} \times \mathrm{Sl}$ & 0.5 & 1.9 & 0.2 & 0.8 & $2.4 *$ & $2.4 *$ & 0.5 & 2.0 & $3.5 * *$ & 1.1 & 0.7 & 2.2 \\
\hline $\mathrm{S} \times \mathrm{F} \times \mathrm{R}$ & 0.9 & 0.2 & 0.2 & 0.3 & 0.3 & 0.8 & 0.0 & 0.3 & 0.5 & 0.6 & 0.9 & 0.5 \\
\hline $\mathrm{S} \times \mathrm{Sl} \times \mathrm{R}$ & 0.2 & 1.6 & 1.8 & 0.9 & 0.2 & 1.1 & 0.3 & 1.6 & 0.2 & 1.3 & 0.0 & 0.7 \\
\hline $\mathrm{F} \times \mathrm{Sl} \times \mathrm{R}$ & 0.8 & 0.6 & 1.0 & 0.8 & 1.1 & 0.2 & 0.9 & 0.1 & 1.0 & 1.1 & 0.8 & 0.6 \\
\hline $\mathrm{S} \times \mathrm{F} \times \mathrm{Sl} \times \mathrm{R}$ & 0.4 & 0.8 & 1.3 & 1.4 & 1.0 & 0.5 & 0.6 & 0.7 & 0.9 & 0.3 & 0.6 & 0.9 \\
\hline
\end{tabular}

Significance levels: $* P<0.05, * * P<0.01, * * * P<0.001$ 


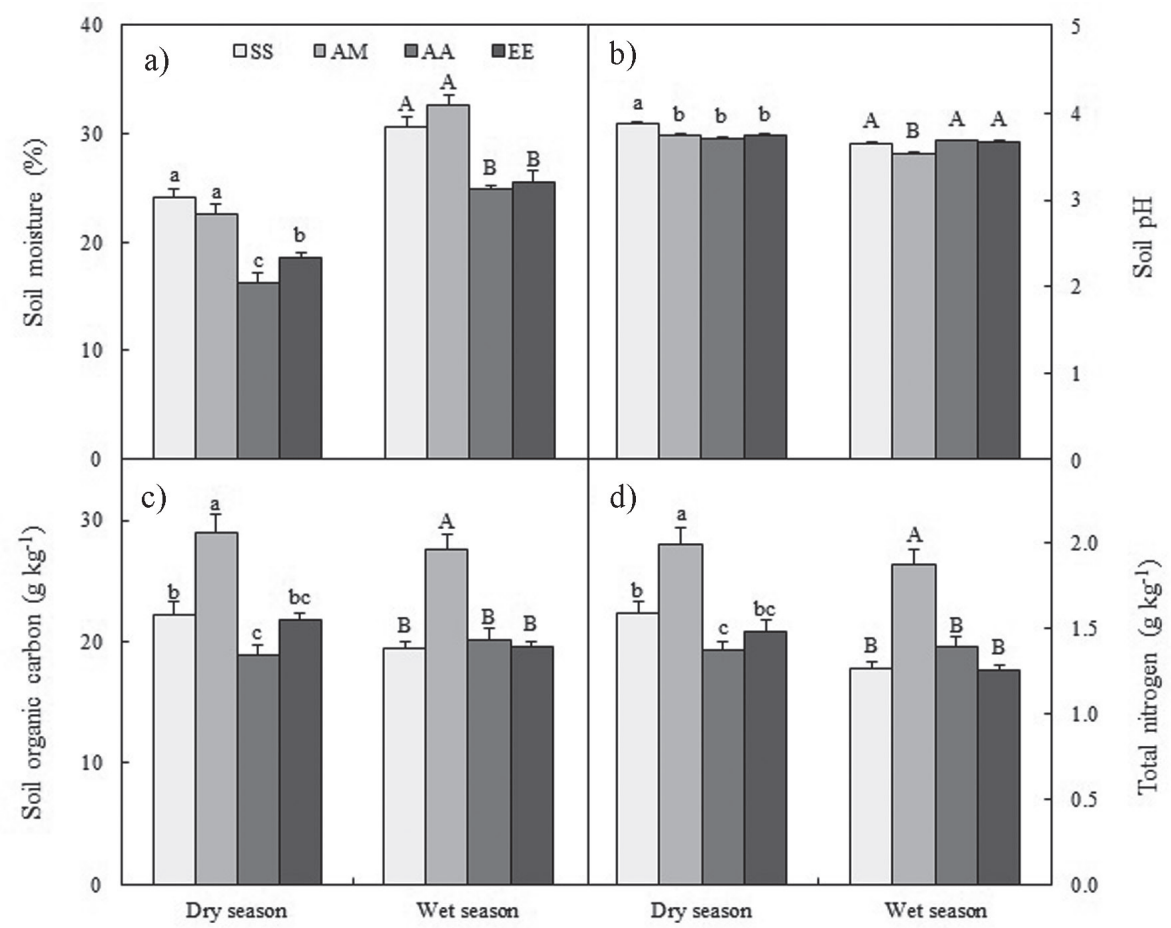

Fig. 1. Soil moisture a), soil pH b), soil organic carbon c), and total nitrogen d) as affected by forest type in dry and wet seasons. Bars indicate standard errors of means $(\mathrm{n}=18)$. SS, AM, AA, and EE represent Schima superba, Acacia mangium, Acacia auriculaeformis, and Eucalyptus exserta, respectively. Data in the columns with the same lowercase letter (dry season) or capital (wet season) are not significantly different $(P>0.05)$.

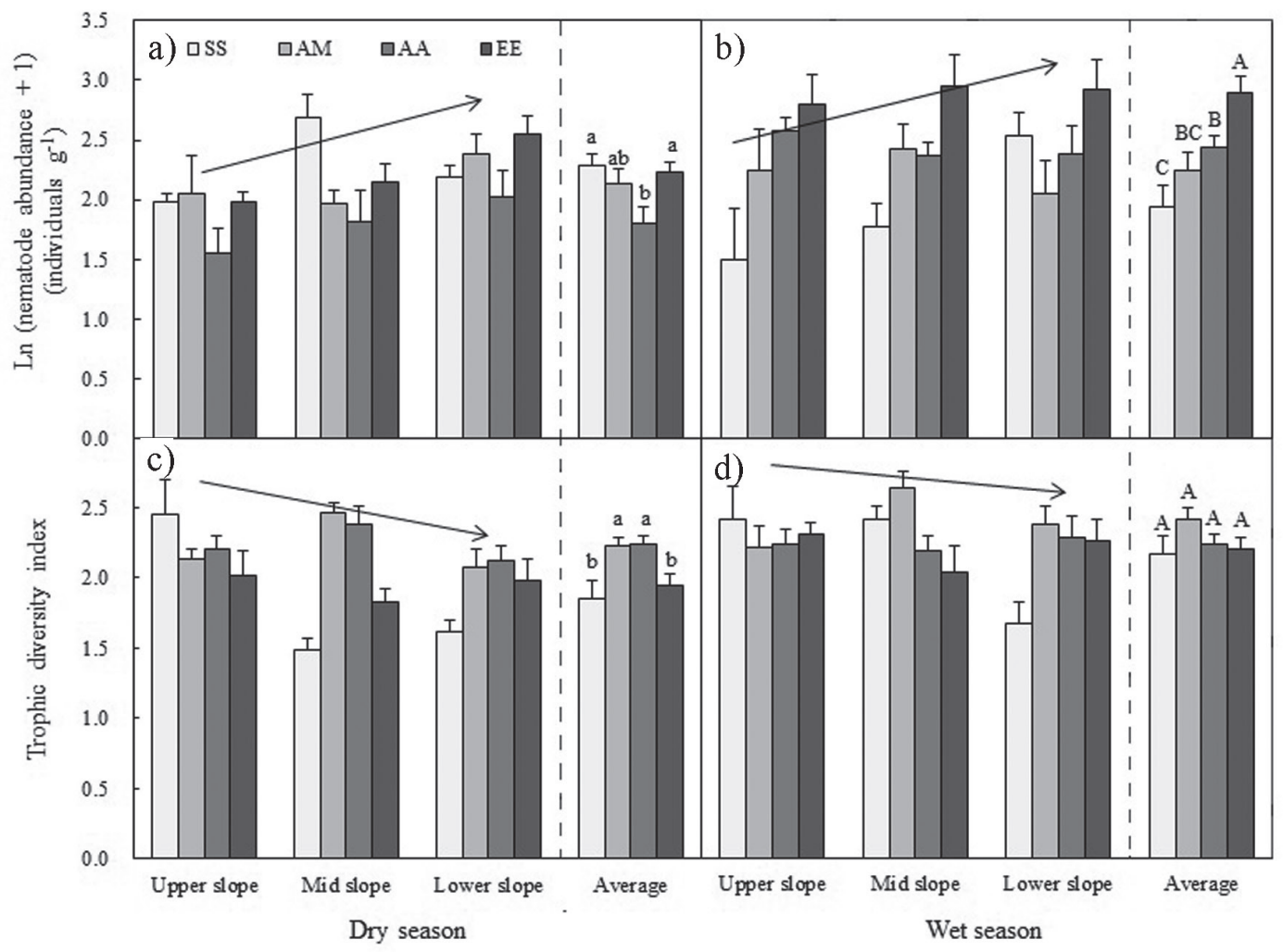

Fig. 2. The effects of forest type and slope on nematode abundance $(a, b)$ and trophic diversity index (c, d) in dry and wet seasons. Bars indicate standard errors of means ( $\mathrm{n}=6$ for upper slope, mid slope, and lower slope; $\mathrm{n}=18$ for average). SS, AM, AA, and EE represent Schima superba, Acacia mangium, Acacia auriculaeformis, and Eucalyptus exserta, respectively. Data in the columns with the same lowercase letter (dry season) or capital (wet season) are not significantly different $(P>0.05)$. 


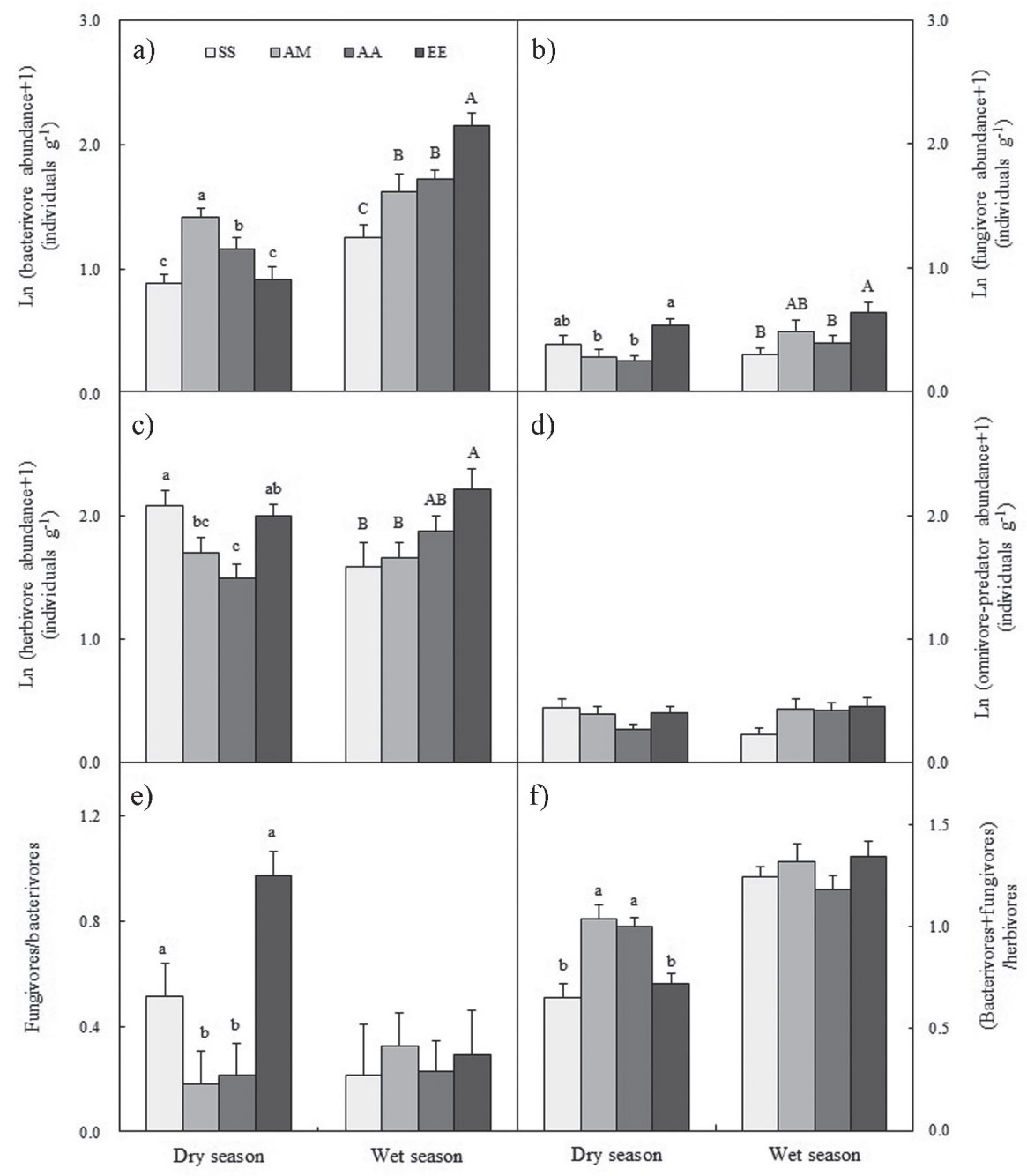

Fig. 3. Bacterivore abundance a), fungivore abundance b), herbivore abundance c), omnivore-predator abundance d), fungivores/ bacterivores e), and (bacterivores+fungivores)/herbivores f) as affected by forest type in dry and wet seasons. Bars indicate standard errors of means ( $\mathrm{n}=18)$. SS, AM, AA, and EE represent Schima superba, Acacia mangium, Acacia auriculaeformis, and Eucalyptus exserta, respectively. Data in the columns with the same lowercase letter (dry season) or capital (wet season) are not significantly different $(P>0.05)$.

in dry season (20.4\%; Fig. 1a). Forest type significantly affected soil moisture (Table 1). Soil moisture in AA and EE were lower than that in SS in both seasons (Fig. 1a). Soil $\mathrm{pH}$ responded significantly to season, forest type, and root zone (Table 1). Mean $\mathrm{pH}$ in wet season were lower than that in dry season (Fig. 1b). Forest type significantly influenced soil organic carbon and total nitrogen (Table 1). Both soil organic carbon and total nitrogen in AM were higher compare with SS both in dry and wet seasons (Figs 1c-d). Both soil organic carbon and total nitrogen of root zone were significantly higher than the non-root zone.

\section{Nematodes and Trophic Groups}

Both nematode abundance and TDI responded significantly to season, forest type, and slope (Table 1). Mean nematode abundance in the wet season was higher than in the dry season (Figs 2a-b). Nematode abundance in AA was lower than that in SS in the dry season average over all slopes (Fig. 2a). In wet season, nematode abundance in AA and EE were higher than that in SS (Fig. 2b). Mean nematode abundance was greater in mid than upper slope, and reached the maximum in the lower slope (Figs 2a-b). Mean TDI in wet season was higher than that in dry season (Figs 2c-d). TDI in AM and AA were higher than that in SS in the dry season average over all slopes (Fig. 2c). Mean TDI was lower in the mid than upper slope, and reached the minimum in the lower slope (Figs 2c-d).

Season significantly impacted bacterivore and fungivore abundance (Table 1). Both bacterivores and fungivores in wet season were higher than those in dry season (Figs 3a-b). Bacterivores in AM and AA were higher compare with SS in dry season (Figs 3a-b). In wet season, bacterivores in all AM, AA, and EE were higher than SS (Fig. 3a). Only fungivores in EE were higher than SS (Fig. 3b). Although no seasonal difference, herbivores 

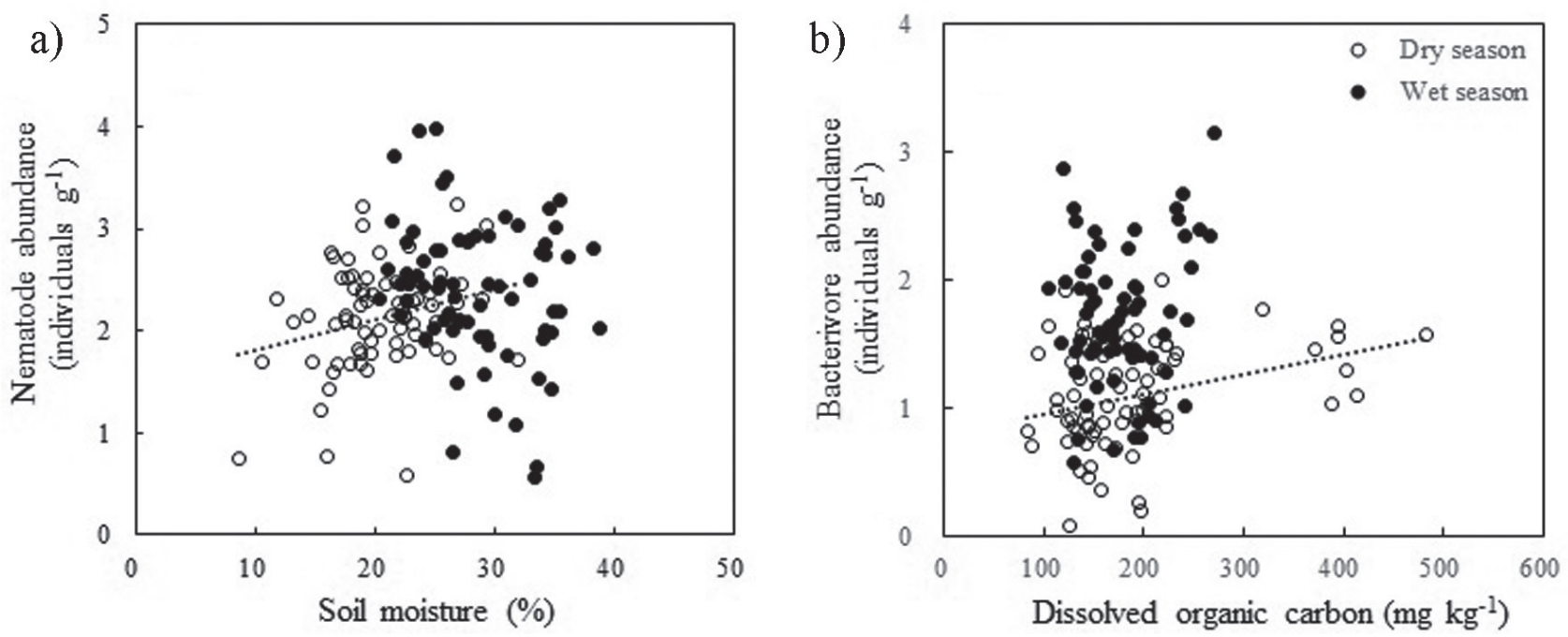

Fig. 4. Positive dependence of nematode abundance on soil moisture and positive dependence of bacterivore abundance on dissolved organic carbon across all the plots in dry season.

varied with forest type (Table 1). Herbivores in AM and AA were lower than that in SS in dry season (Fig. 3c). In wet season, herbivores in EE were higher compare with SS (Fig. 3c). No effect of season or forest type on omnivore-predator abundance was detected (Table 1, Fig. 3d). Season and forest type significantly affected the fungivore/bacterivore ratio (Table 1). Fungivores/ bacterivores in wet season were lower than those in the dry season, and Fungivores/bacterivores in AM and AA were lower than SS in dry season (Fig. 3e). In contrast, (fungivores+bacterivores)/herbivores in wet season were higher than in dry season, and (fungivores+bacterivores)/ herbivores in AM and AA were higher than SS in dry season (Fig. 3f).

\section{Relationships of Nematode with Abiotic Factors}

Nematode abundance linearly increased with soil moisture in dry season ( $\mathrm{r}=0.26, P<0.05$; Fig. 4a). Bacterivore abundance have a positive relationship with dissolved organic carbon in dry season $(\mathrm{r}=0.32, P<0.01$; Fig. 4b).

\section{Discussion}

\section{Effect of Forest Type}

Although our results showed that total soil nematode abundance was not obviously amplified in AM and AA, AM and AA increased bacterivore abundance in both dry and wet seasons. In addition, AM and AA enhanced trophic diversity and microbivore abundance, and depressed herbivore abundance and fungivore/ bacterivore ratio in the dry season (Figs 2-3), indicating that Acacia significantly alter nematode trophic group composition. These findings support our first hypothesis.
Acacia, which produce a great quantity of litterfall of $1.11 \mathrm{~kg} \mathrm{~m}^{-2} \mathrm{y}^{-1}$ and develop larger belowground biomass, could support more decomposers, including bacteria, fungi, and microbivores [21]. Extensive roots of Acacia also form symbioses with soil nitrogen-fixing bacteria [22-23], resulting in bacterial enrichment and subsequent dominance of bacterial energy channel controlled by bottom-up effects [24-25]. The above two ecological processes facilitate the accumulation of soil organic carbon. Lower herbivore abundance in Acacia could be attributed to spatial competition between bacterivores and herbivores. Increasing bacterivore abundance would limit the growth of herbivores.

Soil nematode abundance and some trophic groups, including bacterivores, fungivores, and herbivores, in EE was identical with SS in dry season and higher than SS in wet season (Figs 2-3). In addition, EE did not affect trophic diversity index regardless of season (Fig. 2), suggesting that that of Eucalyptus allelopathy do not inhibit soil nematodes in this study. The results are inconsistent with our second hypothesis. A previous study suggested that Eucalyptus allelopathy would impact understory vegetation, soil microorganisms, and soil fauna through aboveground volatilization, precipitation eluviation, root secretion, and litter deposition releases [26]. However, no obvious reduction of understory vegetation diversity was found in Eucalyptus plantation without human disturbance (data not shown), suggesting that the allelopathic effect of Eucalyptus is weak in this study. Higher nematode abundance and their trophic groups in Eucalyptus could be interpreted in two ways. On the one hand, some insoluble secondary metabolites from Eucalyptus, such as phenolic acid compounds at lower concentrations, may provide an additional carbon source that stimulates soil microbial biomass, microbivore abundance, and herbivore abundance [2729]. On the other hand, Eucalyptus litter decompose much more rapidly [30]. More available nutrients release will be 
helpful for expansion of the soil nematode community in Eucalyptus.

\section{Effect of Season and Interaction with Forest Type}

Total nematode density, bacterivores, and fungivores all showed significantly seasonal variation (Table 1, Figs 2-3), which is in support to our last hypothesis. In the wet season, plants grow quickly and develop greater fine root biomass and litterfall quantity. Higher water and nutrient availability in the wet season is conducive to the expansion of the soil nematode community [31]. Positive effects of soil moisture on nematode abundance and effects of dissolved organic carbon on bacterivore abundance in the dry season have been shown in our results (Fig. 4), which could explain higher nematode abundance in the lower slope due to surface water and nutrient runoff. This is consistent with findings of some previous studies in arid regions [32-33]. However, interactive effects of season and forest type make total and bacterivore nematode abundance independent of soil moisture or dissolved organic carbon in the wet season (Table 1, Fig. 4). For instance, Eucalyptus need to consume a large amount of water through root uptake to support their rapid aboveground biomass accumulation [34], resulting in lower soil moisture (Fig. 1). In tropical and subtropical areas with plenty of rain, especially in the wet season, lower soil moisture will accelerate organic matter decomposition and soil fauna aggregation through increasing oxygen supply and microbial activity [35-36].

\section{Conclusions}

With artificial forests established in degraded hilly area, this study investigated the effects of different monoculture plantations on soil nematode trophic groups. Acacia, particularly Acacia mangium, improve the dominance of bacterial energy channel and suppress plant parasitic nematodes, consequently facilitating soil carbon sequestration, indicating that Acacia mangium as a fastgrowing pioneer tree species could be widely planted in restoring degraded forests in southern China. Plantations of Acacia mixed with native species are also encouraged. A Eucalyptus-enlarging soil nematode community suggests that there is almost no allelopathy in Eucalyptus plantations in this study. Reasonable management of Eucalyptus plantations is helpful for maximizing economic and ecological value in the meantime. This study provides data and theoretical support for tree species selection in restoring degraded ecosystems in southern China.

\section{Acknowledgements}

The authors thank Shenglei Fu for help in setting up the field facilities. The authors thank the editor and reviewer for providing valuable comments and suggestions on earlier versions of this manuscript. This study was financially supported by the National Natural Science Foundation of China (31640011, 31200408) and the Outstanding Youth Training Foundation of Henan University (yqpy20140035).

\section{References}

1. SEVIK H., CETIN M. Effects of water stress on seed germination for select landscape plants. Pol. J. Environ. Stud. 24 (2), 689, 2015.

2. CETIN M. Sustainability of urban coastal area management: A case study on Cide. J. Sustain. Forest. 35 (7), 527, 2016.

3. YIGIT N., SEVIK H., CETIN M., GUL L. Clonal variation in chemical wood characteristics in Hanönü (Kastamonu) Günlüburun black pine (Pinus nigra Arnold. Subsp. Pallasiana (Lamb.) Holmboe) seed orchard. J. Sustain. Forest. 35 (7), 515, 2016.

4. CETIN M., SEVIK H. Measuring the impact of selected plants on indoor $\mathrm{CO}_{2}$ concentrations. Pol. J. Environ. Stud. 25 (3), 973, 2016.

5. SEVIK H., CETIN M., BELKAYALI N. Effects of forests on amounts of $\mathrm{CO}_{2}$ : Case study of Kastamonu and Ilgaz Mountain National Parks. Pol. J. Environ. Stud. 24 (1), 253, 2015.

6. GIBSON L., LEE T.M., KOH L.P., BROOK B.W., GARDNER T.A., BARLOW J., PERES C.A., BRADSHAW C.J.A., LAURANCE W.F., LOVEJOY T.E., SODHI N.S. Primary forests are irreplaceable for sustaining tropical biodiversity. Nature. 478 (7369), 378, 2011.

7. KEENAN R.J., REAMS G.A., ACHARD F., DE FREITAS J.V., GRAINGER A., LINDQUIST E. Dynamics of global forest area: Results from the FAO Global Forest Resources Assessment 2015. Forest Ecol. Manag. 352 (9), 9, 2015.

8. CHAZDON R.L. Beyond deforestation: Restoring forests and ecosystem services on degraded lands. Science. $\mathbf{3 2 0}$ (5882), 1458, 2008.

9. BAUTISTA-CRUZ A., DEL CASTILLO R.F., ETCHEVERS-BARRA J.D., GUTIÉRREZ-CASTORENA M.D.C., BAEZ A. Selection and interpretation of soil quality indicators for forest recovery after clearing of a tropical montane cloud forest in Mexico. Forest Ecol. Manag. 277 (8), 74, 2012

10. GONG X., LIU Y., LI Q., WEI X., GUO X., NIU D., ZHANG W., ZHANG J., ZHANG L. Sub-tropic degraded red soil restoration: Is soil organic carbon build-up limited by nutrients supply. Forest Ecol. Manag. 300 (7), 77, 2013.

11. ONAINDIA M., AMETZAGA-ARREGI I., SEBASTIÁN M.S., MITXELENA A., RODRÍGUEZ-LOINAZ G., PEÑA L., ALDAY J.G. Can understory native woodland plant species regenerate under exotic pine plantations using natural succession? Forest Ecol. Manag. 308 (11), 136, 2013.

12. ZHAO C., MIAO Y., YU C., ZHU L., WANG F., JIANG L., HUI D., WAN S. Soil microbial community composition and respiration along an experimental precipitation gradient in a semiarid steppe. Sci. Rep. 6 (4), 24317, 2016.

13. NEHER D.A. Nematode communities in organically and conventionally managed agricultural soils. J. Nematol. 31 (2), 142, 1999.

14. SHAO Y., ZHANG W., SHEN J., ZHOU L., XIA H., SHU W., FERRIS H., FU S. Nematodes as indicators of soil recovery in tailings of a lead/zinc mine. Soil Biol. Biochem. 40 (8), 2040, 2008 
15. KLASS J.R., PETERS D.P.C., TROJAN J.M., THOMAS S.H. Nematodes as an indicator of plant-soil interactions associated with desertification. Appl. Soil Ecol. 58 (7), 66, 2012.

16. UGARTE C.M., ZABORSKI E.R., WANDER M.M. Nematode indicators as integrative measures of soil condition in organic cropping systems. Soil Biol. Biochem. 64 (9), 103, 2013.

17. CAIXETA L.B., PEREIRA T.J., CASTAÑEDA N.E.N., CARES J.E. Nematode communities as indicators of the status of a soil ecosystem influenced by mining practices in Brazil. Nematology. 18 (3), 265, 2016.

18. YANG L., LIU N., REN H., WANG J. Facilitation by two exotic Acacia: Acacia auriculiformis and Acacia mangium as nurse plants in South China. Forest Ecol. Manag. 257 (8), 1786, 2009.

19. WANG J., REN H., YANG L., LI D., GUO Q. Soil seed banks in four 22-year-old plantations in South China: Implications for restoration. Forest Ecol. Manag. 258 (9), 2000, 2009.

20. BLISS T., POWERS T.O., BRASSIL C.E. The spatial influence of aboveground diversity on belowground communities. Ecosphere. 1 (2-3), art7, 2010.

21. KEITH A.M., BROOKER R.W., OSLER G.H.R., CHAPMAN S.J., BURSLEM D.F.R.P., VAN DER WALL R. Strong impacts of belowground tree inputs on soil nematode trophic composition. Soil Biol. Biochem. 41 (6), 1060, 2009.

22. BINI D., DOS SANTOS C.A., BOUILLET J.P., DE MORAIS GONÇALVES J.L., CARDOSO E.J.B.N. Eucalypus grandis and Acacia mangium in monoculture and intercropped plantations: Evolution of soil and litter microbial and chemical attributes during early stages of plant development. Appl. Soil Ecol. 63 (1), 57, 2013.

23. HUANG X., LIU S., WANG H., HU Z., LI Z., YOU Y. Changes of soil microbial biomass carbon and community composition through mixing nitrogen-fixing species with Eucalyptus urophylla in subtropical China. Soil Biol. Biochem. 73 (6), 42, 2014.

24. ANDRIUZZI W.S., KEITH A.M., BARDGETT R.D., VAN DER WAL R. Soil nematode assemblage responds weakly to grazer exclusion on a nutrient-rich seabird island. Eur. J. Soil Biol. 58 (9-10), 38, 2013.

25. ZHAO J., WANG X., WANG X., FU S. Legume-soil interactions: legume addition enhances the complexity of the soil food web. Plant Soil. 385 (1-2), 273, 2014
26. CHU C., MORTIMER P.E., WANG H., WANG Y., LIU X., YU S. Allelopathic effects of Eucalyptus on native and introduced tree species. Forest Ecol. Manag. 323 (7), 79, 2014.

27. DE NOBILI M., CONTIN M., MONDINI C., BROOKES P.C. Soil microbial biomass is triggered into activity by trace amounts of substrate. Soil Biol. Biochem. 33 (9), 1163, 2001.

28. QU X.H., WANG J.G. Effect of amendments with different phenolic acids on soil microbial biomass, activity, and community diversity. Appl Soil Ecol. 39 (2), 172, 2008.

29. ZHANG J., SALAHUDDIN, JI L., YANG L.X., WANG H.R., YOU L.X. Effects of larch (Larix gmelinii) phenolic acids on Manchurian ash (Fraxinus mandshurica) soil microbial community structure. Allelopathy J. 37 (1), 123, 2016.

30. LI Z.A., PENG S.L., RAE D.J., ZHOU G.Y. Litter decomposition and nitrogen mineralization of soils in subtropical plantation forests of southern China, with special attention to comparisons between legumes and nonlegumes. Plant Soil. 229 (1), 105, 2001.

31. CHEN D., LAN Z., BAI X., GRACE J.B., BAI Y. Evidence that acidification-induced declines in plant diversity and productivity are mediated by changes in below-ground communities and soil properties in a semi-arid steppe. J. Ecol. 101 (5), 1322, 2013.

32. LIANG W., STEINBERGER Y. Temporal changes in nematode community structure in a desert ecosystem. J. Arid Environ. 48 (3), 267, 2001.

33. STEINBERGER Y., LIANG W., SAVKINA E., MESHI T., BARNESS G. Nematode community composition and diversity associated with a topoclimatic transect in a rain shadow desert. Eur. J. Soil Biol. 37 (4), 315, 2001.

34. HUBBARD R.M., STAPE J., RYAN M.G., ALMEIDA A.C., ROJAS J. Effects of irrigation on water use and water use efficiency in two fast growing Eucalyptus plantations. Forest Ecol. Manag. 259 (9), 1714, 2010.

35. GARCIA-PAUSAS J., CASALS P., ROMANYÀ J. Litter decomposition and faunal activity in Mediterranean forest soils: effects of $\mathrm{N}$ content and the moss layer. Soil Biol. Biochem. 36 (6), 989, 2004.

36. BRANDT L.A., KING J.Y., MILCHUNAS D.G. Effects of ultraviolet radiation on litter decomposition depend on precipitation and litter chemistry in a shortgrass steppe ecosystem. Global Change Biol. 13 (10), 2193, 2007. 